4

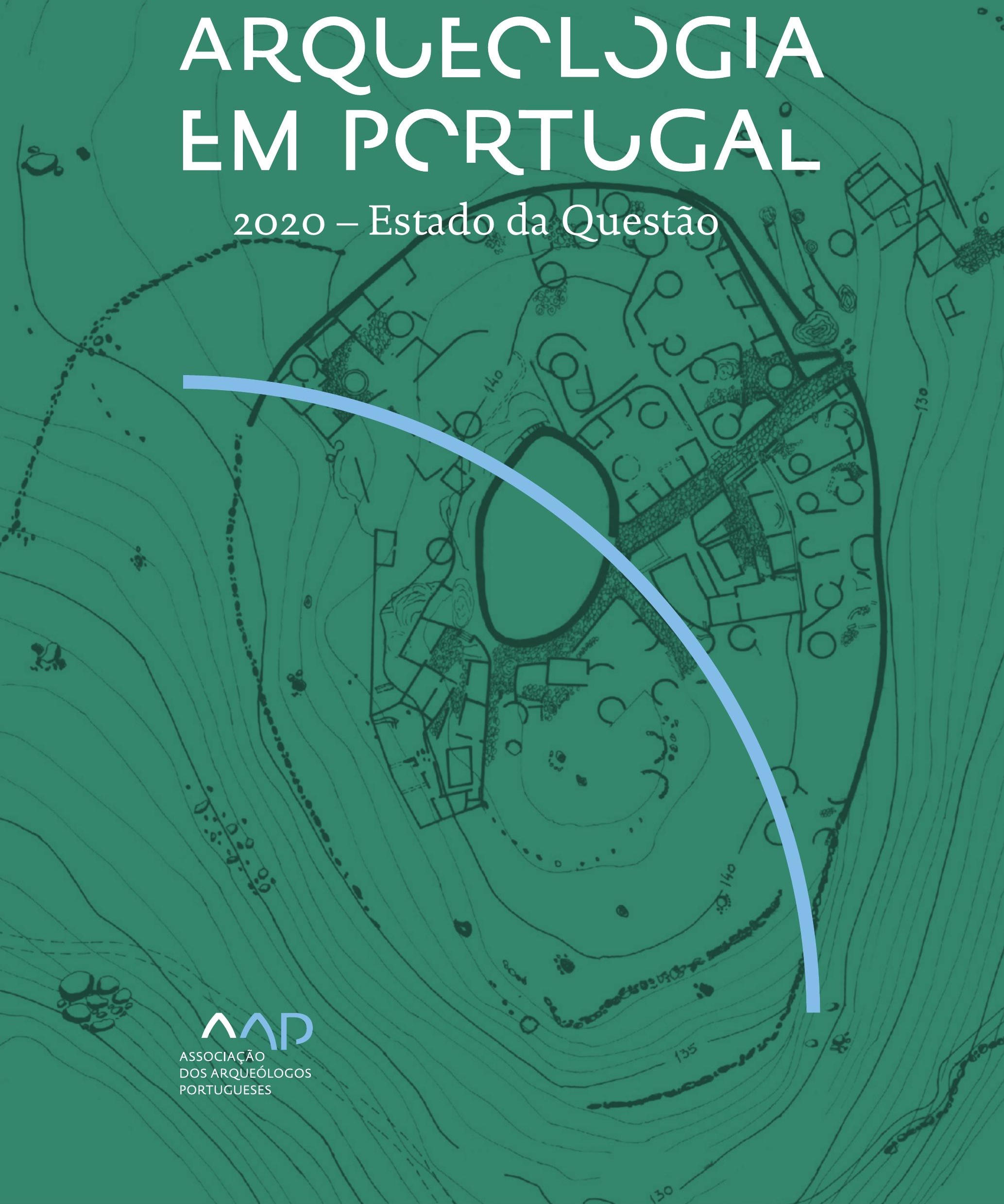


Coordenação editorial: José Morais Arnaud, César Neves e Andrea Martins Design gráfico: Flatland Design

AAP - ISBN: 978-972-9451-89-8

CITCEM - ISBN: 978-989-8970-25-1

Associação dos Arqueólogos Portugueses e CITCEM

Lisboa, 2020

O conteúdo dos artigos é da inteira responsabilidade dos autores. Sendo assim a Associação dos Arqueólogos Portugueses declina qualquer responsabilidade por eventuais equívocos ou questões de ordem ética e legal.

Desenho de capa:

Planta do castro de Monte Mozinho (Museu Municipal de Penafiel).

\section{$\hat{\wedge} \mathrm{P}$}

DOS ARQUEÓLOGOS PORTUGUESES

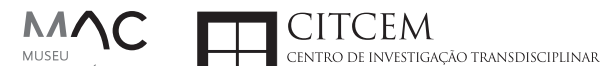
MUSEU
ARQUELLÓGICO
DO CARMO
U.PORTO

FLUP FACULDADE DE LETRAS
UNIVERSIDADE DO PORTO

Apoio

EC para a Ciência 


\section{Índice}

15 Prefácio

José Morais Arnaud

\section{Historiografia e Teoria}

17 Território, comunidade, memória e emoção: a contribuição da história da arqueologia (algumas primeiras e breves reflexões)

Ana Cristina Martins

25 Como descolonizar a arqueologia portuguesa?

Rui Gomes Coelho

41 Arqueologia e Modernidade: uma revisitação pessoal e breve de alguns aspetos da obra homónima de Julian Thomas de 2004

Vítor Oliveira Jorge

57 Dados para a História das Mulheres na Arqueologia portuguesa, dos finais do século XIX aos inícios do século XX: números, nomes e tabelas

Filipa Dimas / Mariana Diniz

73 Retractos da arqueologia portuguesa na imprensa: (in)visibilidades no feminino

Catarina Costeira / Elsa Luís

85 Arqueologia e Arqueólogos no Norte de Portugal Jacinta Bugalhão

101 Vieira Guimarães (1864-1939) e a arqueologia em Tomar: uma abordagem sobre o território e as gentes

João Amendoeira Peixoto / Ana Cristina Martins

115 Os memoráveis? A arqueologia algarvia na imprensa nacional e regional na presente centúria (2001-2019): características, visões do(s) passado(s) e a arqueologia

enquanto marca

Frederico Agosto / João Silva

129 A Evolução da Arqueologia Urbana e a Valorização Patrimonial no Barlavento Algarvio: Os casos de Portimão e Silves

Artur Mateus / Diogo Varandas / Rafael Boavida

\section{Gestão, Valorização e Salvaguarda do Património}

145 O Caderno Reivindicativo e as condições de trabalho em Arqueologia Miguel Rocha / Liliana Matias Carvalho / Regis Barbosa / Mauro Correia / Sara Simões / Jacinta Bugalhão / Sara Brito / Liliana Veríssimo Carvalho / Richard Peace / Pedro Peça / Cézer Santos

155 Os Estudos de Impacte Patrimonial como elemento para uma estratégia sustentável de minimização de impactes no âmbito de reconversões agrícolas Tiago do Pereiro

165 Salvaguarda de Património arqueológico em operações florestais: gestão e sensibilização Filipa Bragança / Gertrudes Zambujo / Sandra Lourenço / Belém Paiva / Carlos Banha / Frederico Tatá Regala / Helena Moura / Jacinta Bugalhão / João Marques / José Correia / Pedro Faria / Samuel Melro

179 Os valores do Património: uma investigação sobre os Sítios Pré-históricos de Arte Rupestre do Vale do Rio Côa e de Siega Verde José Paulo Francisco 
189 Conjugando recursos arqueológicos e naturais para potenciar as visitas ao Geoparque Litoral de Viana do Castelo (Noroeste de Portugal)

Hugo A. Sampaio / Ana M.S. Bettencourt / Susana Marinho / Ricardo Carvalhido

203 Áreas de Potencial Arqueológico na Região do Médio Tejo: Modelo Espacial Preditivo Rita Ferreira Anastácio / Ana Filipa Martins / Luiz Oosterbeek

223 Património Arqueológico e Gestão Territorial: O contributo da Arqueologia para a revisão do PDM de Avis

Ana Cristina Ribeiro

237 A coleção arqueológica do extinto Museu Municipal do Porto - Origens, Percursos e Estudos

Sónia Couto

251 Valpaços - uma nova carta arqueológica

Pedro Pereira / Maria de Fátima Casares Machado

263 Arqueologia na Cidade de Peniche

Adriano Constantino / Luís Rendeiro

273 Arqueologia Urbana: a cidade de Lagos como caso de Estudo Cátia Neto

285 Estratégias de promoção do património cultural subaquático nos Açores. O caso da ilha do Faial

José Luís Neto / José Bettencourt / Luís Borges / Pedro Parreira

297 Carta Arqueológica da Cidade Velha: Uma primeira abordagem

Jaylson Monteiro / Nireide Tavares / Sara da Veiga / Claudino Ramos / Edson Brito /

Carlos Carvalho / Francisco Moreira / Adalberto Tavares

311 Antropologia Virtual: novas metodologias para a análise morfológica e funcional Ricardo Miguel Godinho / Célia Gonçalves

\section{Didáctica da Arqueologia}

327 Como os projetos de Arqueologia podem contribuir para uma comunidade culturalmente mais consciente Alexandra Figueiredo / Claúdio Monteiro / Adolfo Silveira / Ricardo Lopes

337 Educação Patrimonial - Um cidadão esclarecido é um cidadão ativo! Ana Paula Almeida

351 A aproximação da Arqueologia à sala de aula: um caso de estudo no $3^{\circ}$ ciclo do Ensino Básico Luís Serrão Gil

363 Arqueologia 3.o - Pensar e comunicar a Arqueologia para um futuro sustentável Mónica Rolo

377 “Conversa de Arqueólogos" - Divulgar a Arqueologia em tempos de Pandemia Diogo Teixeira Dias

389 Escola Profissional de Arqueologia: desafios e oportunidades Susana Nunes / Dulcineia Pinto / Júlia Silva / Ana Mascarenhas

399 Os Museus de Arqueologia e os Jovens: a oferta educativa para o público adolescente Beatriz Correia Barata / Leonor Medeiros

411 O museu universitário como mediador entre a ciência e a sociedade: o exemplo da secção de arqueologia no Museu de História Natural e da Ciência da Universidade do Porto (MHNC-UP)

Rita Gaspar 
421 Museu de Lanifícios: Real Fábrica de Panos. Atividades no âmbito da Arqueologia Beatriz Correia Barata / Rita Salvado

427 Arqueologia Pública e o caso da localidade da Mata (Torres Novas) Cláudia Manso / Ana Rita Ferreira / Cristiana Ferreira / Vanessa Cardoso Antunes

431 Do sítio arqueológico ao museu: um percurso (também) didático Lídia Fernandes

447 Estão todos convidados para a Festa! E para dançar também... O projecto do Serviço Educativo do Museu Arqueológico do Carmo na $5^{\underline{a}}$ Edição da Festa da Arqueologia Rita Pires dos Santos

459 O “Clã de Carenque”, um projeto didático de arqueologia Eduardo Gonzalez Rocha

469 Mediação cultural: peixe que puxa carroça nas Ruínas Romanas de Troia Inês Vaz Pinto / Ana Patrícia Magalhães / Patrícia Brum / Filipa Santos

481 Didática Arqueológica, experiências do Projeto Mértola Vila Museu Maria de Fátima Palma / Clara Rodrigues / Susana Gómez / Lígia Rafael

\section{Arte Rupestre}

497 Os inventários de arte rupestre em Portugal Mila Simões de Abreu

513 O projeto FIRST-ART - conservação, documentação e gestão das primeiras manifestações de arte rupestre no Sudoeste da Península Ibérica: as grutas do Escoural e Maltravieso Sara Garcês / Hipólito Collado / José Julio García Arranz / Luiz Oosterbeek / António Carlos Silva / Pierluigi Rosina / Hugo Gomes / Anabela Borralheiro Pereira / George Nash / Esmeralda Gomes / Nelson Almeida / Carlos Carpetudo

523 Trabalhos de documentação de arte paleolítica realizados no âmbito do projeto PalæoCôa André Tomás Santos / António Fernando Barbosa / Luís Luís / Marcelo Silvestre / Thierry Aubry

537 Imagens fantasmagóricas, silhuetas elusivas: as figuras humanas na arte do Paleolítico Superior da região do Côa Mário Reis

$55^{1}$ Os motivos zoomórficos representados nas placas de tear de Vila Nova de São Pedro (Azambuja, Portugal) Andrea Martins / César Neves / José M. Arnaud / Mariana Diniz

571 Arte Rupestre do Monte de Góios (Lanhelas, Caminha). Síntese dos resultados dos trabalhos efectuados em 2007-2009 Mário Varela Gomes

599 Gravuras rupestres de barquiformes no Monte de S. Romão, Guimarães, Noroeste de Portugal Daniela Cardoso

613 Círculos segmentados gravados na Bacia do Rio Lima (Noroeste de Portugal): contributos para o seu estudo Diogo Marinho / Ana M.S. Bettencourt / Hugo Aluai Sampaio

631 Equídeos gravados no curso inferior do Rio Mouro, Monção (NW Portugal). Análise preliminar Coutinho, L.M. / Bettencourt, A.M.S / Sampaio, Hugo A.S

645 Paletas na Arte Rupestre do Noroeste de Portugal. Inventário preliminar Bruna Sousa Afonso / Ana M. S. Bettencourt / Hugo A. Sampaio 


\section{Pré-História}

661 O projeto Miño/Minho: balanço de quatro anos de trabalhos arqueológicos Sérgio Monteiro-Rodrigues / João Pedro Cunha-Ribeiro / Eduardo Méndez-Quintas / Carlos Ferreira / Pedro Xavier / José Meireles / Alberto Gomes / Manuel Santonja / Alfredo Pérez-González

677 A ocupação paleolítica da margem esquerda do Baixo Minho: a indústria lítica do sítio de Pedreiras 2 (Monção, Portugal) e a sua integração no contexto regional Carlos Ferreira / João Pedro Cunha-Ribeiro / Sérgio Monteiro-Rodrigues / Eduardo Méndez-Quintas / Pedro Xavier / José Meireles / Alberto Gomes / Manuel Santonja / Alfredo Pérez-González

693 O sítio acheulense do Plistocénico médio da Gruta da Aroeira Joan Daura / Montserrat Sanz / Filipa Rodrigues / Pedro Souto / João Zilhão

703 As sociedades neandertais no Barlavento algarvio: modelos preditivos com recurso aos SIG

Daniela Maio

715 A utilização de quartzo durante o Paleolítico Superior no território dos vales dos rios Vouga e Côa

Cristina Gameiro / Thierry Aubry / Bárbara Costa / Sérgio Gomes / Luís Luís / Carmen Manzano / André Tomás Santos

733 Uma perspetiva diacrónica da ocupação do concheiro do Cabeço da Amoreira (Muge, Portugal) a partir da tecnologia lítica Joana Belmiro / João Cascalheira / Célia Gonçalves

745 Novos dados sobre a Pré-história Antiga no concelho de Palmela. A intervenção arqueológica no sítio do Poceirão I

Michelle Teixeira Santos

757 Problemas em torno de Datas Absolutas Pré-Históricas no Norte do Alentejo Jorge de Oliveira

771 Povoamento pré-histórico nas áreas montanhosas do NO de Portugal: o Abrigo 1 de Vale de Cerdeira Pedro Xavier / José Meireles / Carlos Alves

783 Apreciação do povoamento do Neolítico Inicial na Baixa Bacia do Douro. A Lavra I (Serra da Aboboreira) como caso de estudo Maria de Jesus Sanches

797 O Processo de Neolitização na Plataforma do Mondego: os dados do Sector C do Outeiro dos Castelos de Beijós (Carregal do Sal)

João Carlos de Senna-Martinez / José Manuel Quintã Ventura / Andreia Carvalho / Cíntia Maurício

823 Novos trabalhos na Lapa da Bugalheira (Almonda, Torres Novas) Filipa Rodrigues / Pedro Souto / Artur Ferreira / Alexandre Varanda / Luís Gomes / Helena Gomes / João Zilhão

837 A pedra polida e afeiçoada do sítio do Neolítico médio da Moita do Ourives (Benavente, Portugal)

César Neves

857 Casal do Outeiro (Encarnação, Mafra): novos contributos para o conhecimento do povoamento do Neolítico final na Península de Lisboa.

Cátia Delicado / Carlos Maneira e Costa / Marta Miranda / Ana Catarina Sousa

873 Stresse infantil, morbilidade e mortalidade no sítio arqueológico do Neolítico Final/ Calcolítico ( $4^{\circ}$ e $3^{\circ}$ milénio a.C.) do Monte do Carrascal 2 (Ferreira do Alentejo, Beja) Liliana Matias de Carvalho / Sofia N. Wasterlain 
885 Come together: O Conjunto Megalítico das Motas (Monção, Viana do Castelo) e as expressões Campaniformes do Alto Minho Ana Catarina Basílio / Rui Ramos

899 Trabalhos arqueológicos no sítio Calcolítico da Pedreira do Poio Carla Magalhães / João Muralha / Mário Reis / António Batarda Fernandes

913 O sítio arqueológico de Castanheiro do Vento. Da arquitectura do sítio à arquitectura de um território João Muralha Cardoso

925 Estudo zooarqueológico das faunas do Calcolítico final de Vila Nova de São Pedro (Azambuja, Portugal): Campanhas de 2017 e 2018 Cleia Detry / Ana Catarina Francisco / Mariana Diniz / Andrea Martins / César Neves / José Morais Arnaud

943 As faunas depositadas no Museu Arqueológico do Carmo provenientes de Vila Nova de São Pedro (Azambuja): as campanhas de 1937 a 1967 Ana Catarina Francisco / Cleia Detry / César Neves / Andrea Martins / Mariana Diniz / José Morais Arnaud

959 Análise funcional de material lítico em sílex do castro de Vila Nova de S. Pedro (Azambuja, Portugal): uma primeira abordagem Rafael Lima

971 O recinto da Folha do Ouro 1 (Serpa) no contexto dos recintos de fossos calcolíticos alentejanos

António Carlos Valera / Tiago do Pereiro / Pedro Valério / António M. Monge Soares

\section{Proto-História}

987 Produção de sal marinho na Idade do Bronze do noroeste Português. Alguns dados para uma reflexão

Ana M. S. Bettencourt / Sara Luz / Nuno Oliveira / Pedro P. Simões / Maria Isabel C. Alves / Emílio Abad-Vidal

1001 A estátua-menir do Pedrão ou de São Bartolomeu do Mar (Esposende, noroeste de Portugal) no contexto arqueológico da fachada costeira de entre os rios Neiva e Cávado Ana M. S. Bettencourt / Manuel Santos-Estévez / Pedro Pimenta Simões / Luís Gonçalves

1015 O Castro do Muro (Vandoma/Baltar, Paredes) - notas para uma biografia de ocupação da Idade do Bronze à Idade Média

Maria Antónia D. Silva / Ana M. S. Bettencourt / António Manuel S. P. Silva / Natália Félix

1031 Do Bronze Final à Idade Média - continuidades e hiatos na ocupação de Povoados em Oliveira de Azeméis João Tiago Tavares / Adriaan de Man

1041 As faunas do final da Idade do Bronze no Sul de Portugal: leituras desde o Outeiro do Circo (Beja)

Nelson J. Almeida / Íris Dias / Cleia Detry / Eduardo Porfírio / Miguel Serra

1055 A Espada do Monte das Oliveiras (Serpa) - uma arma do Bronze Pleno do Sudoeste Rui M. G. Monge Soares / Pedro Valério / Mariana Nabais / António M. Monge Soares

1065 São Julião da Branca (Albergaria-a-Velha) - Investigação e valorização de um povoado do Bronze Final

António Manuel S. P. Silva / Paulo A. P. Lemos / Sara Almeida e Silva / Edite Martins de Sá

1083 Do castro de S. João ao Mosteiro de Santa Clara: notícia de uma intervenção arqueológica, em Vila do Conde Rui Pinheiro 
1095 O castro de Ovil (Espinho), um quarto de século de investigação - resultados e questões em aberto

Jorge Fernando Salvador / António Manuel S. P. Silva

1111 O Castro de Salreu (Estarreja), um povoado proto-histórico no litoral do Entre Douro e Vouga

Sara Almeida e Silva / António Manuel S. P. Silva / Paulo A. P. Lemos / Edite Martins de Sá

1127 Castro de Nossa Senhora das Necessidades (Sernancelhe): uma primeira análise artefactual Telma Susana O. Ribeiro

${ }_{1141}$ A cividade de Bagunte. O estado atual da investigação Pedro Brochado de Almeida

1153 Zoomorfos na cerâmica da Idade do Ferro no NW Peninsular: inventário, cronologias e significado Nuno Oliveira / Cristina Seoane

1163 Vasos gregos em Portugal: diferentes maneiras de contar a história do intercâmbio cultural na Idade do Ferro

Daniela Ferreira

1175 Os exotica da necrópole da Idade do Ferro do Olival do Senhor dos Mártires (Alcácer do Sal) no seu contexto regional

Francisco B. Gomes

\section{Antiguidade Clássica e Tardia}

1191 O uso de madeira como combustível no sítio da Quinta de Crestelos (Baixo Sabor): da Idade do Ferro à Romanização Filipe Vaz / João Tereso / Sérgio Simões Pereira / José Sastre / Javier Larrazabal Galarza / Susana Cosme / José António Pereira / Israel Espi

1207 Cultivos de Época Romana no Baixo Sabor: continuidade em tempos de mudança? João Pedro Tereso / Sérgio Simões Pereira / Filipe Santos / Luís Seabra / Filipe Vaz

1221 A casa romana na Hispânia: aplicação dos modelos itálicos nas províncias ibéricas Fernanda Magalhães / Diego Machado / Manuela Martins

1235 As pinturas murais romanas da Rua General Sousa Machado, n. ${ }^{5}$ 1, Chaves José Carvalho

1243 Trás do Castelo (Vale de Mir, Pegarinhos, Alijó) - Uma exploração agrícola romana do Douro

Tony Silvino / Pedro Pereira

1255 A sequência de ocupação no quadrante sudeste de Bracara Augusta: as transformações de uma unidade doméstica Lara Fernandes / Manuela Martins

1263 Os Mosaicos com decoração geométrica e geométrico-vegetalista dos sítios arqueológicos da área do Conuentus Bracaraugustanus. Novas abordagens quanto à conservação, restauro, decoração e datação Maria de Fátima Abraços / Licínia Wrench

1277 “Casa Romana” do Castro de São Domingos (Cristelos, Lousada): Escavação, Estudo e Musealização Paulo André de P. Lemos

1291 A arqueobotânica no Castro de Guifões (Matosinhos, Noroeste de Portugal): O primeiro estudo carpológico

Luís Seabra / Andreia Arezes / Catarina Magalhães / José Varela / João Pedro Tereso 
1305 Um Horreum Augustano na Foz do Douro (Monte do Castelo de Gaia, Vila Nova de Gaia) Rui Ramos

1311 Ponderais romanos na Lusitânia: padrões, formas, materiais e contextos de utilização Diego Barrios Rodríguez

1323 Um almofariz centro-itálico na foz do Mondego

Marco Penajoia

1335 Estruturas romanas de Carnide - Lisboa Luísa Batalha / Mário Monteiro / Guilherme Cardoso

1347 O contexto funerário do sector da "necrópole NO" da Rua das Portas de S. Antão (Lisboa): o espaço, os artefactos, os indivíduos e a sua interconectividade na interpretação do passado Sílvia Loja, José Carlos Quaresma, Nelson Cabaço, Marina Lourenço, Sílvia Casimiro, Rodrigo Banha da Silva, Francisca Alves-Cardoso

${ }_{1361}$ Povoamento em época Romana na Amadora - resultados de um projeto pluridisciplinar Gisela Encarnação / Vanessa Dias

1371 A Arquitectura Residencial em Mirobriga (Santiago do Cacém): contributo a partir de um estudo de caso Filipe Sousa / Catarina Felício

${ }_{1385}$ O fim do ciclo. Saneamento e gestão de resíduos nos edifícios termais de Mirobriga (Santiago do Cacém)

Catarina Felício / Filipe Sousa

1399 Balsa, Topografia e Urbanismo de uma Cidade Portuária Vítor Silva Dias / João Pedro Bernardes / Celso Candeias / Cristina Tété Garcia

1413 No Largo das Mouras Velhas em Faro (2017): novas evidências da necrópole norte de Ossonoba e da sua ocupação medieval Ricardo Costeira da Silva / Paulo Botelho / Fernando Santos / Liliana Nunes

1429 Instrumentos de pesca recuperados numa fábrica de salga em Ossonoba (Faro) Inês Rasteiro / Ricardo Costeira da Silva / Paulo Botelho

1439 A Necrópole Romana do Eirô, Duas Igrejas (Penafiel): intervenção arqueológica de 2016 Laura Sousa / Teresa Soeiro

1457 Ritual, descarte ou afetividade? A presença de Canis lupus familiaris na Necrópole Noroeste de Olisipo (Lisboa)

Beatriz Calapez Santos / Sofia Simões Pereira / Rodrigo Banha da Silva / Sílvia Casimiro / Cleia Detry / Francisca Alves Cardoso

1467 Dinâmicas económicas em Bracara na Antiguidade Tardia Diego Machado / Manuela Martins / Fernanda Magalhães / Natália Botica

1479 Cerâmicas e Vidros da Antiguidade Tardia do Edifício sob a Igreja do Bom Jesus (Vila Nova de Gaia) Joaquim Filipe Ramos

1493 Novos contributos para a topografia histórica de Mértola no período romano e na Antiguidade Tardia Virgílio Lopes

\section{8. Época Medieval}

1511 Cerâmicas islâmicas no Garb setentrional "português": algumas evidências e incógnitas Constança dos Santos / Helena Catarino / Susana Gómez / Maria José Gonçalves / Isabel Inácio / Gonçalo Lopes / Jacinta Bugalhão / Sandra Cavaco / Jaquelina Covaneiro / Isabel Cristina Fernandes / Ana Sofia Gomes 
1525 Contributo para o conhecimento da cosmética islâmica, em Silves, durante a Idade Média Rosa Varela Gomes

1537 Yábura e o seu território - uma análise histórico-arqueológica de Évora entre os séculos VIII-XII José Rui Santos

1547 A encosta sul do Castelo de Palmela - resultados preliminares da escavação arqueológica Luís Filipe Pereira / Michelle Teixeira Santos

1559 A igreja de São Lourenço (Mouraria, Lisboa): um conjunto de silos e de cerâmica medieval islâmica

Andreia Filipa Moreira Rodrigues

1571 O registo material de movimentações populacionais no Médio Tejo, durante os séculos XII-XIII. Dois casos de "sunken featured buildings", nos concelhos de Cartaxo e Torres Novas Marco Liberato / Helena Santos / Nuno Santos

1585 O nordeste transmontano nos alvores da Idade média. Notas para reflexão Ana Maria da Costa Oliveira

1601 Sepulturas escavadas na rocha do Norte de Portugal e do Vale do Douro: primeiros resultados do Projecto SER-NPVD

Mário Jorge Barroca / César Guedes / Andreia Arezes / Ana Maria Oliveira

1619 "Portucalem Castrum Novum" entre o Mediterrâneo e o Atlântico: o estudo dos materiais cerâmicos alto-medievais do arqueossítio da rua de D. Hugo, nํ. 5 (Porto) João Luís Veloso

1627 A Alta Idade Média na fronteira de Lafões: notas preliminares sobre a Arqueologia no Concelho de Vouzela

Manuel Luís Real / Catarina Tente

1641 Um conjunto cerâmico medieval fora de portas: um breve testemunho aveirense Susana Temudo

${ }_{1651}$ Os Lóios do Porto: uma perspetiva integrada no panorama funerário da Baixa Idade Média à Época Moderna em meios urbanos em Portugal

Ana Lema Seabra

1659 O Caminho Português Interior de Santiago como eixo viário na Idade Média Pedro Azevedo

1665 Morfologia Urbana: Um exercício em torno do Castelo de Ourém André Donas-Botto / Jaqueline Pereira

1677 Intervenção arqueológica na Rua Marquês de Pombal/Largo do Espírito Santo (Bucelas, Loures)

Florbela Estêvão / Nathalie Antunes-Ferreira / Dário Ramos Neves / Inês Lisboa

1691 O Cemitério Medieval do Poço do Borratém e a espacialidade funerária na cidade de Lisboa Inês Belém / Vanessa Filipe / Vasco Noronha Vieira / Sónia Ferro / Rodrigo Banha da Silva

1705 Um Espaço Funerário Conventual do séc. XV em Lisboa: o caso do Convento de São Domingos da Cidade Sérgio Pedroso / Sílvia Casimiro / Rodrigo Banha da Silva / Francisca Alves Cardoso

\section{9. Época Moderna e Contemporânea}

1721 Arqueologia Moderna em Portugal: algumas reflexões críticas em torno da quantificação de conjuntos cerâmicos e suas inferências históricas e antropológicas Rodrigo Banha da Silva / André Bargão / Sara da Cruz Ferreira

1733 Faianças de dois contextos entre os finais do século XVI e XVIII do Palácio dos Condes de Penafiel, Lisboa

Martim Lopes / Tomás Mesquita 
1747 Um perfil de consumo do século XVIII na foz do Tejo: O caso do Mercado da Ribeira, Lisboa Sara da Cruz Ferreira / Rodrigo Banha da Silva / André Bargão

1761 Os Cachimbos dos Séculos XVII e XVIII do Palácio Mesquitela e Convento dos Inglesinhos (Lisboa)

Inês Simão / Marina Pinto / João Pimenta / Sara da Cruz Ferreira / André Bargão / Rodrigo Banha da Silva

1775 "Tomar os fumos da erua que chamão em Portugal erua sancta». Estudo de Cachimbos provenientes da Rua do Terreiro do Trigo, Lisboa

Miguel Martins de Sousa / José Pedro Henriques / Vanessa Galiza Filipe

1787 Cachimbos de Barro Caulínitico da Sé da Cidade Velha (República de Cabo Verde)

Rodrigo Banha da Silva / João Pimenta / Clementino Amaro

1801 Algumas considerações sobre espólio não cerâmico recuperado no Largo de Jesus (Lisboa) Carlos Boavida

1815 Adereços de vidro, dos séculos XVI-XVIII, procedentes do antigo Convento de Santana de Lisboa (anéis, braceletes e contas)

Joana Gonçalves / Rosa Varela Gomes / Mário Varela Gomes

1837 Da ostentação, luxo e poder à simplicidade do uso quotidiano: arqueologia e simbologia de joias e adornos da Idade Moderna Portuguesa Jéssica Iglésias

1849 Os amuletos em Portugal - dos objetos às superstições: o coral vermelho Alexandra Vieira

1865 Cerâmicas de Vila Franca de Xira nos séculos XV e XVI Eva Pires

1879 «Não passa por teu o que me pertence». Marcas de individualização associadas a faianças do Convento de Nossa Senhora de Aracoeli, Alcácer do Sal Catarina Parreira / Íris Fragoso / Miguel Martins de Sousa

1891 Cerâmica de Leiria: alguns focos de produção

Jaqueline Pereira / André Donas-Botto

1901 Os Fornos na Rua da Biquinha, em Óbidos Hugo Silva / Filipe Oliveira

1909 A casa de Pêro Fernandes, contador dos contos de D. Manuel I: o sítio arqueológico da Silha do Alferes, Seixal (século XVI) Mariana Nunes Ferreira

1921 O Alto da Vigia (Sintra) e a vigilância e defesa da costa Alexandre Gonçalves / Sandra Santos

1937 O contexto da torre sineira da Igreja de Santa Maria de Loures Paulo Calaveira / Martim Lopes

1949 A Necrópole do Hospital Militar do Castelo de São Jorge e as práticas funerárias na Lisboa de Época Moderna Susana Henriques / Liliana Matias de Carvalho / Ana Amarante / Sofia N. Wasterlain

1963 SAND - Sarilhos Grandes Entre dois Mundos: o adro da Igreja e a Paleobiologia dos ossos humanos recuperados

Paula Alves Pereira / Roger Lee Jesus / Bruno M. Magalhães

1975 Expansão urbana da vila de Cascais no século XVII e XVIII: a intervenção arqueológica na Rua da Vitória no 15 a 17

Tiago Pereira / Vanessa Filipe

1987 Novos dados para o conhecimento do Urbanismo de Faro em época Moderna Ana Rosa 
1995 Um exemplo de Arqueologia Urbana em Alcoutim: o Antigo Edifício dos CTT Marco Fernandes / Marta Dias / Alexandra Gradim / Virgílio Lopes / Susana Gómez Martínez

2007 Palácio dos Ferrazes (Rua das Flores/Rua da Vitória, Porto): a cocheira de Domingos Oliveira Maia

Francisco Raimundo

2021 As muitas vidas de um edifício urbano: História, Arqueologia e Antropologia no antigo Recreatório Paroquial de Penafiel Helena Bernardo / Jorge Sampaio / Marta Borges

2035 O convento de Nossa Senhora da Esperança de Ponta Delgada: o contributo da arqueologia para o conhecimento de um monumento identitário João Gonçalves Araújo / N’Zinga Oliveira

2047 Arqueologia na ilha do Corvo... em busca da capela de Nossa Senhora do Rosário Tânia Manuel Casimiro / José Luís Neto / Luís Borges / Pedro Parreira

2059 Perdidos à vista da Costa. Trabalhos arqueológicos subaquáticos na Barra do Tejo Jorge Freire / José Bettencourt / Augusto Salgado

2071 Arqueologia marítima em Cabo Verde: enquadramento e primeiros resultados do projecto CONCHA

José Bettencourt / Adilson Dias / Carlos Lima / Christelle Chouzenoux / Cristóvão Fonseca / Dúnia Pereira / Gonçalo Lopes / Inês Coelho / Jaylson Monteiro / José Lima / Maria Eugénia Alves / Patrícia Carvalho / Tiago Silva

2085 Trabalhos arqueológicos na Cidade Velha (Ribeira Grande de Santiago, Cabo Verde): reflexões sobre um projecto de investigação e divulgação patrimonial André Teixeira / Jaylson Monteiro / Mariana Mateus / Nireide Tavares / Cristovão Fonseca / Gonçalo C. Lopes / Joana Bento Torres / Dúnia Pereira / André Bargão / Aurélie Mayer / Bruno Zélie / Carlos Lima / Christelle Chouzenoux / Inês Henriques / Inês Pinto Coelho / José Lima / Patrícia Carvalho / Tiago Silva

2103 A antiga fortificação de Quelba / Khor Kalba (E.A.U.). Resultados de quatro campanhas de escavações, problemáticas e perspectivas futuras Rui Carita / Rosa Varela Gomes / Mário Varela Gomes / Kamyar Kamyad

2123 Colónias para homens novos: arqueologia da colonização agrária fascista no noroeste ibérico Xurxo Ayán Vila / José Mạ . Señorán Martín 


\title{
UM ALMOFARIZ CENTRO-ITÁLICO NA FOZ DO MONDEGO
}

\author{
Marco Penajoia ${ }^{1}$
}

\begin{abstract}
RESUMO
O Museu Municipal Santos Rocha realizou uma Exposição e Colóquio intitulada: "Santos Rocha, Arqueologia e Territórios da Figueira da Foz”. Este evento visou a sensibilização para a arqueologia e para o património arqueológico local, através da exposição de alguns espólios museológicos, nunca antes expostos e inéditos, entre os quais um fragmento de almofariz romano. Pretendemos com este artigo divulgar e desenvolver o estudo deste artefacto. Trata-se de um mortarium de fabrico centro-itálico e de tipologia Dramont $\mathrm{D}_{2}$ identificado na zona denominada de Igreja Velha do Negrote-Alqueidão. Este tipo de artefacto, atendendo à sua especificidade, vem apoiar a investigação no que concerne ao grau de romanização na foz do Mondego. Uma posição geográfica com elevada dinâmica flúvio-marítima.
\end{abstract}

Palavras-chave: Almofariz, Dramont D2, Foz do Mondego, Navegação, Museu Municipal Santos Rocha.

\begin{abstract}
The Santos Rocha Municipal Museum held an Exhibition and Colloquium entitled: "Santos Rocha, Archaeology and Territories of Figueira da Foz". This event is aimed at raising awareness for archaeology and the local archaeological heritage, through the exhibition of some museum exhibits never before exposed and unpublished, including a fragment of a Roman mortar. With this article, we intend to disseminate and develop the study of this artefact. It is a centre-italic mortarium and Dramont D2 typology identified in the area called Igreja Velha do Negrote-Alqueidão. This type of artefact, given its specificity, supports the investigation regarding the degree of romanization at the mouth of the Mondego river. A geographical position with high fluvial-maritime dynamics.
\end{abstract}

Keywords: Mortar, Dramont D2, Mouth of Mondego, Navigation, Santos Rocha Municipal Museum.

\section{TERRITÓRIO - VALORES TOPONÍMICOS}

Esta zona de estudo (Figura 1 e 2) integra registos toponímicos ${ }^{2}$ a considerar: Alqueidão, de etimologia árabe, pode advir de <ár.alqtun, ou seja «acampamento" (Fernandes, 1999, p. 38-39), ou derivar de al-qaddân, "o calcário", "o cascalho", e de al-gaytân, "os campos», "os jardins", "as hortas" (Alves, 2013, p. 195). Já o Paião pode enquadrar-se numa problemática relacionada com a administração dos territórios romanos. Veja-se pagus, que se refere ao marco fixado na terra e, consequentemente, ao território delimitado por esses marcos. $\mathrm{Na}$ área urbana do
Paião existe o microtopónimo - Marco, este volta a registar-se a $9 \mathrm{~km}$ Oeste, já em território de Soure e a 850 m do sítio romano da Madanela ${ }^{3}$. Neste âmbito é possível problematizar o território do Paião no contexto de pagus. Esta designação, no mundo romano, poderá expressar uma certa extensão do território rural, uma subdivisão rural da civitas. Aos pagi romanos e suevo-visogodos vieram suceder as "terras» e os "territórios» da administração condal dos séculos IX e seguintes (Dias, 1980). Jorge de Alarcão descreve as paróquias e pagi como "aglomerados urbanos já existentes e importantes na época romana, aglomerados que terão conservado,

\footnotetext{
1. Município da Figueira da Foz - Museu Municipal Santos Rocha; Centro de História da Sociedade e da Cultura - Universidade de Coimbra; arqueologia.museu@cm-figfoz.pt / penajoia@fl.uc.pt
}

2. A análise da distribuição dos antigos povoamentos deve ter em conta a avaliação toponímica e espacial (Ruiz Zapatero, 1988, p. 43).

3. De Man e Ruivo, 2009. 
na época suévica, os seus primitivos nomes, eventualmente já com alguma alteração fonética ou ortográfica" (Alarcão, 2001, p. 31).

Com a Reconquista e com as mudanças de povoamento da Península, os pagi passaram muitas vezes a ser designados paenas pelo onomástico. Noutros casos mantiveram a totalidade do nome, geralmente adulterado. Assim deve ter acontecido com as terras denominadas Paio, ou Pai. Embora nenhum estudo nos prove que Paio vem do termo Pagus, julgamos que gramaticalmente e filologicamente isso é possível. Num documento do século XI Pajo aparece já a significar "terra». Assim, os autores listaram cartograficamente dois sítios na Figueira da Foz com este valor toponímico - Paião e Pai Penela, em Quiaios (Dias, 1980).

Outros valores toponímicos em torno desta zona alertam-nos para potenciais indicadores arqueológicos, alguns já confirmados: Bizorreiro de Castela, Cabaço, Casal Verde, Facho, Lagoinha, Portela e Telhada. Em frente a esta zona, e na margem direita do Mondego, temos as posições geostratégicas de Lares, Outeiro de Mosquitos, Monte do Cavalo ${ }^{4}$ e Monte da Amoreira ${ }^{5}$, estes últimos com vestígios de ocupação romana.

\section{ENQUADRAMENTO GEOMORFOLÓGICO}

Os rios são, efetivamente, os grandes eixos de desenvolvimento de um território, pelo que nunca estarão imunes a uma mutação antrópica constante. O sítio da Igreja Velha do Negrote apresenta uma posição geoestratégica na margem esquerda do paleoestuário do Mondego, próximo do estrangulamento natural entre o Alqueidão e a posição de Moinho do Almoxarife/Pena ${ }^{6}$, a montante. Salienta-se a comunicação náutica com a entrada do Rio Pranto e a zona do vale do Alqueidão. Assim, define-se como um sítio com condições naturais de excelência para a ocupação antrópica e de apoio ao controlo náutico, portuário e defensivo do passado. Nessa perspetiva, Vasco Mantas realça as alterações ocorridas na linha de costa, no final do período romano. Estas terão sido causadas por questões geomorfo-

\footnotetext{
4. Alarcão, 1988.

5. Ferreira e Pinto, 2017; Penajoia, no prelo.

6. Recentemente identificou-se uma possível lasca de descorticamento (Penajoia, 2014-2015).
}

lógicas, que se manifestaram em "colmatagem de reentrâncias, progressão de cabedelos, alterações de lagunas, assoreamento da parte vestibular de rios" (Mantas, 1999, p. 137-138). É perante esta realidade, com escassez de investigação relativamente ao povoamento antigo, que antigos portos romanos e medievais deixaram de ser alcançados (Idem, 1999). A dinâmica geomorfológica demonstra que os vales confluentes a esta zona estariam no passado preenchidos por pequenas rias e esteiros, que desaguavam para a linha de água atual. Em algumas margens ainda é possível verificar alguns cortes com cascalheira de um terraço fluvial7.

Analisando de uma forma preliminar a planimetria em torno do Negrote, verificamos parcelários que se orientam maioritariamente para o paleoestuário e com parcelas a rondar, em média, os $1200 \mathrm{~m}^{2}$. Apresenta um desenvolvimento urbano, que se enquadra no sistema de tipo "aldeia-rua". Esta zona apesar de defendida a Este por uma encosta em socalcos, que atinge no seu topo cerca de $35 \mathrm{~m}$ de altitude, evidencia mais a norte, no Alqueidão, um elemento morfogenético - tipo interflúvio onde hoje se processa a Rua da Fonte Velha.

\section{VIAS DE COMUNICAÇÃO - NAVEGAÇÃO}

Dada a especificidade deste território, uma análise arqueológica deverá saber conjugar a Arqueologia do povoamento com a Arqueologia de meio-aquático. Esta última não se restringe às zonas submersas, incluindo também todos os locais cujas condições físicas tenham permitido, ou permitam, a implantação de estruturas de apoio associadas à prática náutica. Quanto à ocorrência de vestígios arqueológicos romanos no estuário do Mondego, para o período romano, salientamos o achado de Maiorca, que nos remete para um possível naufrágio de uma embarcação romano-republicana (Imperial, 2017). Junto ao Porto de Sanfins, define-se um estreitamento natural com povoamento romano, que envolve na margem direita os cabeços do Mosquito, Cavalo ${ }^{8} \mathrm{e}$

\footnotetext{
7. Para o Baixo Mondego são distinguidos vários níveis de terraços do Quaternário. Alguns investigadores apontam para níveis entre os 50, 30 e $15 \mathrm{~m}$; outros para os 70-9o m, 40-6o m, 20-35 m, 5-15 m; sendo o de 25-40 m o que tem maior expressão cartográfica (Ribeiro e Patrício, 1942 e Soares, 1966, apud Vilaça, 1988, p. 11).

8. Alarcão, 1988.
} 
Amoreira, e na margem esquerda o monte de Reveles, com estreita ligação ao sítio de Sevelha (Penajoia, 2011; 2012; 2013). As redes de um barco na sua faina trouxeram à tona recipientes de dolia $\mathrm{e}$ anforae, que se crê serem provenientes também de um naufrágio de uma nave romana ${ }^{9}$. Estes achados permitem comprovar que o Mondego teria uma excelente dinâmica náutica neste período, aliás já comprovada pela longa diacronia do complexo portuário de Santa Olaia, sobretudo na Idade do Ferro. Por outro lado, não podemos esquecer que este rio era a via principal para o escoamento da produção de sal e indústrias associadas (produzidas na sua foz). Nos parcelários fósseis, que ainda se detetam junto aos campos de arroz, é possível verificar que estariam associados a antigas salinas.

Assim, é pertinente focar as questões relacionadas com a construção naval e as explorações salineiras. Aqui existia uma população dispersa de pescadores e salineiros, que sempre caracterizaram a foz do rio, e que estão incipientemente estudadas/os. Sabemos que existiam marinhas e que o Mosteiro de Santa Cruz estaria interessado na sua aquisição para a exploração do sal e do pescado, neste caso na margem direita (Alarcão, 2004, p. 103). Não esquecendo também a complementaridade da produção oleira, que seria essencial nesta atividade. A esse respeito, Santos Rocha identificou vários vestígios de fornos para produção cerâmica romana na área circundante (Rocha, 1897; Penajoia, no prelo). Trata-se realmente de uma posição geográfica sugestiva para complexos de olaria, incluindo materiais anfóricos que dinamizariam uma economia de povoados costeiros, onde a indústria da salga de peixe e de preparados piscícolas seriam determinantes (Blot, 2003). Neste campo, Carlos Fabião assinala as dificuldades que uma investigação pode sentir no objetivo de detetar centros de exploração de recursos marinhos e de olarias, que estariam localizadas em áreas litorais (seja na costa, fundos de estuário, ou zonas lagunares). Neste contexto, segundo o investigador, enquadra-se o território a norte do complexo portuário da Estremadura - o Mondego. Este vasto estuário estabelece-se numa importante tradição histórica de recursos marinhos, inserido numa costa onde escasseiam fundeadouros, e onde se deverá projetar investigações norteadas para a identificação de vestígios da Lusitânia Romana, tendo sempre a

9. Cortez, 1957, p. 120-122. noção das antigas geografias e não o presente quadro paisagístico (Fabião, 2004, p. 383-384).

As próprias vias terrestres apontam para o contexto económico e cultural existente nesta zona da foz. Algumas rotas e caminhos tiveram desde sempre um foco relevante na circulação de pessoas e animais sendo perpetuados, por exemplo, até à área da Serra da Lousã/Açor/Sobral de São Miguel e Casegas (Covilhã) conhecidas por: "A Rota do Sal ou Estrada Real" até ao século XX (Ribeiro; Joaquinito e Pereira, 2010, p. 204).

No período romano, pode apontar-se a existência de uma reciprocidade no relacionamento entre núcleo urbano e núcleo rural. Esse relacionamento não era, porém, igualitário, mas essencial para permitir o controlo imperial sobre o território colonial, sendo reflexo da influência política/militar, e condicionado pela distribuição e hierarquização dos povoamentos.

Quanto à distribuição destes, verificamos, na área de estudo, uma relação muito próxima com o sistema hídrico Mondego/Pranto, ao longo do qual se implantaram os sítios de ocupação romana. Os povoados estabelecem-se normalmente em encostas suaves e voltadas a SE, tendo em vista a acessibilidade fluvial e a sua adaptação à atracagem das embarcações.

Nesta perspetiva efetuámos uma análise espacial referente a sítios de ocupação romana no paleoestuário do Mondego e seus afluentes. É possível observar que as distâncias entre eles em linha reta rondam, em média, os $6 \mathrm{~km}$.

Finalmente, apercebemo-nos também que o território é limitado, na zona mais baixa, pelo traçado ferroviário, sendo uma via de comunicação de especial interesse para o estudo dos indicadores arqueológicos, visto que a sua implantação veio substituir muitos dos ancoradouros e portos fluviais existentes no passado.

\section{O SÍTIO ARQUEOLÓGICO DA IGREJA VELHA DO NEGROTE E O ALMOFARIZ}

Esta zona do Alqueidão/Paião/Negrote, ainda que pouco documentada na época, foi de alguma forma caracterizada por Santos Rocha aquando da sua incursão no vizinho castro de Bizorreiro de Castela. "O outeiro é muito ingreme de todos os lados, e só facilmente acessível pela encosta de Oeste. Do cimo descobre-se um soberbo panorama. Ao Sul ergue-se 
a Serra do Paião. A Este, Nordeste e Norte os campos e o Mondego: toda a margem direita, com os seus relevos e povoações até Ferrestelo; e na margem esquerda, Abrunheira, Revelles” (Rocha, 1909, p. 245). Do Paião temos algumas notícias de materiais romanos, nomeadamente as coligidas por Belchior da Cruz, que dá conta da entrada de quatro fragmentos de dolium no museu (Cruz, 1899-19oo, p. 180).

O sítio da Igreja Velha do Negrote enquadra-se no âmbito legal da Carta Arqueológica da Figueira da Foz e respetivas salvaguardas, integradas no PDM. O sítio está protegido por uma zona arqueológica - ZA14 - e classificado como Valor Arqueológico n. VA66. Daqui são provenientes os fragmentos de uma ânfora de tipologia Haltern 7o, datável dos meados do século I a.C. aos meados/finais do I d.C. (Figura 3), e de um almofariz (mortarium), que se conservam na reserva de arqueologia do Museu Municipal. Analisando o almofariz, verificámos que a entrada desta peça no acervo do Museu está registada no Catálogo Geral com o n.ำ4374 e com a designação de "fragmento de um vaso" (Rocha, 1905, p. 140). Trata-se de um almofariz de tipologia Dramont D2, de fabrico centro-itálico e sem marca de oleiro conservada (Figura 4 e 5). Esta tipologia está relacionada com a abundante representatividade destes almofarizes no naufrágio, com o mesmo nome, sucedido na costa francesa (Joncheray, 1972). Esta forma itálica, primeira área de produção, está também representada na Tarraconense e foi igualmente elaborada na Gália (Quaresma, 2006, p. 151).

Para além de Lisboa e seu território, identificam-se exemplares, nomeadamente em Conimbriga (Alarcão \& alii, 1976, p. 75, desenho n.ํ137), Santarém (Arruda e Viegas, 2004) e Braga (Morais, 2004). A escassez de mais resultados referentes a esta tipologia parece agora começar a ser invertida e a ganhar alguma representatividade, pois a falta de estudos publicados será certamente uma causa a assinalar (Mota \& alii, 2016-2017, p. 180). A presença desta tipologia em meio rural também se aproxima da questão náutica, visto que são identificados, algumas vezes, próximo da linha de costa, não só em Portugal, mas também na vizinha Espanha (Moscardó Sabater, 2008; Trelis Martí, 2012).

A análise deste exemplar leva-nos a enquadrá-lo na época Flaviana conforme, análise do bordo tipo 3 de Aguarod Otal (1991, p. 141), e nas semelhanças com um exemplar de Caeseraugusta (Idem, 1991, fig. 34-3).
Atualmente o estudo de almofarizes romanos começa a integrar uma especialidade dentro da ceramologia romana. Para além da cozinha, poderiam estar relacionados com "outras funções como as ligadas à obtenção de produtos medicinais ou de beleza (por exemplo, a preparação de cremes e pinturas com fins de aplicação cosmética), ou com a maceração de vísceras de peixes destinada à preparação de molhos do tipo garum ou de liquamen" (Sepúlveda $\mathbb{E}$ alii, 2007, p. 256). O estudo destes almofarizes permite analisar a dimensão económica romana, apoiar a sua definição cronológica, bem como avaliar a dinâmica de aquisição de hábitos culturais itálicos (Silva, 2015, p. 1).

Ao nível da descrição morfológica do almofariz em estudo, trata-se de um fragmento de bordo largo desenvolvido externamente e espessado, de secção amendoada. É dotado de paredes espessas de tendência hemisférica. Amplo vertedor, com canal de drenagem de forma troncopiramidal e flanqueado por dois sulcos oblíquos. Apresenta as seguintes dimensões: altura máxima - 6,2 cm; largura máxima conservada $-7,0 \mathrm{~cm}$; espessura da parede $-1,8 \mathrm{~cm}$; diâmetro $-44 \mathrm{~cm}$, aproximadamente.

Quanto às características das pastas, estas apresentam uma origem vulcânica, ricas em minerais ferro-magnesianos, com tons amarelo e rosa claros (Aguarod Otal, 1991, p. 141).

A tipologia D2 difere do D1, também pelo seu maior peso e profundidade (Luezas Pascual, 2001, p. 77).

No Laboratório de Petrologia ${ }^{10}$ foi efetuada uma análise petrográfica ao almofariz (Figura 6). No que concerne à pasta, esta é globalmente de granulometria fina com coloração interior e exterior tendencialmente bege/rosada 5 YR $8 / 4^{11}$. Já no que diz respeito aos elementos não plásticos (ENPS) observam-se minerais geralmente não angulosos e de calibre pequeno: micas, biotites, moscovite, quartzos, piroxenas alongadas e chamota. A zona de superfície aparenta um acabamento de engobe e parece apresentar alguns alisamentos para a definição da morfologia da peça. Evidencia, nas zonas laterais do vertedor e no reverso, uma pasta bastante granulosa com matriz de quartzo e alguns nódulos de cal. Trata-se possivelmente de argamassa. Esta observação levanta

10. DCT - Departamento de Ciências da Terra - Universidade de Coimbra. Utilizámos o microscópio estereográfico Nikon SMZ 8oo.

11. Munsell Colour Chart. 
uma problemática em torno do segundo momento funcional desta peça. Estaria adaptada e consolidada numa estrutura, ou simplesmente reaproveitada num qualquer aparelho construtivo local?

Afigura-se promissora a metodologia de prospeção sistemática desta área. Recentemente desencadeámos uma batida ao local, com paragem num outro sítio próximo e de interesse, designado de Barra. Aqui, a $200 \mathrm{~m}$ de uma capela seiscentista e junto a uma quinta voltada a SE, identificámos vários fragmentos de cerâmica comum de pasta alaranjada e de construção - tégula. A cerca de $1500 \mathrm{~m}$ NE do sítio do Negrote, na zona baixa do Alqueidão, existe um troço de calçada e uma ponte já referenciados como valores patrimoniais em PDM.

Na subida para o Negrote/Alqueidão, acompanhados por alguns residentes, parámos junto à escola primária, onde os mesmos nos "localizaram" o sítio da "Igreja Velha”. Aqui identificámos uma estrutura em muito mau estado de conservação. Esta ruína está voltada para Oeste, ou seja, para o Atlântico. Apresenta-se alinhada por antigos socalcos de vinhas com uma orientação de $30^{\circ} \mathrm{NE}$, a $500 \mathrm{~m} \mathrm{NE}$ da Escola.

Este sítio levanta-nos alguns problemas na sua identificação exacta, desde logo pela ambiguidade da posição da dita igreja. Em segundo lugar, porque a maior parte dos terrenos que vão desde a escola à igreja restaurada estão registados no livro de matrizes prediais do concelho como de Igreja Velha. Ou seja, numa distância aproximada de $300 \mathrm{~m}$ em linha reta. Apesar de nos faltar comprovar o núcleo central do sítio, conseguimos verificar, a partir das ruínas, alguma dispersão de materiais cerâmicos de feição romana, e que nos levaram até ao talude da estrada principal no sentido Negrote-Alqueidão. Neste talude é possível verificar pontualmente na sua estratigrafia, uma linha de argamassa e alguns materiais cerâmicos muito rolados.

Muito próximo do Negrote, a cerca de $2 \mathrm{~km}$ Oeste e na margem oposta ao rio Pranto, encontram-se águas termais exploradas certamente no período romano. Helena Frade e José Beleza (1992, p. 517) dão conta da estância termal n. ${ }^{\circ} 38$ - Nossa Senhora do Pranto, atualmente, Termas da Azenha.

Trata-se, de facto, de uma zona que certamente terá sido explorada pela sua posição de grande domínio visual, quer para o Atlântico, Mondego/Pranto, quer para antigos povoados da margem direita e esquerda. Esta situação também conferiu uma apetência náu- tica, devido à sua proximidade com o paleoestuário, bem como a utilização de matérias-primas locais (pedra calcária), que lhes forneceriam um papel de fixação e dinamismo. Assim, não é de estranhar a presença de materiais importados neste território, como é o exemplo deste almofariz.

\section{AGRADECIMENTOS}

Agradecemos à Dr. - Margarida Perrolas e à Dr..$^{\underline{a}}$ Ana Ferreira o apoio incondicional a esta investigação, bem como à equipa técnica da Divisão de Cultura do Município da Figueira da Foz.

À Doutora Carmen Aguarod Otal, Ao Prof. Doutor Carlos Fabião e à Prof. ․ Doutora Lídia Catarino, o nosso agradecimento pelos esclarecimentos que nos prestaram relativamente ao almofariz.

\section{BIBLIOGRAFIA}

AGUAROD OTAL, Carmen - (1991) Cerámica común romana de cocina en la Tarraconense. Zaragoza: Institución "Fernando el Católico".

AGUAROD OTAL, Carmen (2017) - Cerámica común de mesa y de cocina en el valle del Ebro y producciones periféricas. In FERNÁNDEZ OCHOA, Carmen; MORILLO, Ángel; ZARZALEJOS, Mar, eds. - Manual de cerámica romana II: cerámicas romanas de época altoimperial en Hispania : importación y producción. Alcalá de Henares: Museo Arqueológico Regional, pp. 15-95.

ALARCÃO, Jorge de; DELGADO, Manuela; MAYET, Françoise; ALARCÃO, Adília Moutinho e PONTE, Salete da, (1976) - Fouilles de Conimbriga VI, Céramiques diverses et verres. Paris, De Boccard.

ALARCÃO, Jorge de (1988) - Roman Portugal, Coimbra, England: Aris \& Phillips Ltd. Vol.II, fasc.2.

ALARCÃO, Jorge de (2001) - As paróquias suévicas do território actualmente português. In F. VILLARe M.P.FERNÁNDEZ ÁLVAREZ (eds.), Religión, lengua y cultura prerromanas de Hispania. Salamanca: Universidad de Salamanca, pp. 29-59.

ALARCÃO, Jorge de (2004) - In territorio colimbrie: lugares velhos (e alguns deles deslembrados) do Mondego. Lisboa: IPA (Trabalhos de Arqueologia, 38).

ALVES, Adalberto (2013) - Dicionário de Arabismos da Língua Portuguesa. Lisboa: Imprensa Nacional-Casa da Moeda.

ARRUDA, A. Margarida.; VIEGAS, Catarina. (2004) - Les mortiers de l'Alcáçova de Santarém (Portugal). In Société Française d'Étude de la Céramique Antique en Gaule: actes du Congrès de Vallauris, 2O-23 mai 2004. Marseille: Société Française d’Étude de la Céramique Antique en Gaule, pp.341-349. 
BLOT, M. Luísa Pinheiro (2003) - Os portos na origem dos centros urbanos: contributo para a arqueologia das cidades marítimas e flúvio-marítimas em Portugal, IPA, Lisboa.

DE MAN, Adriaan; RUIVO, José (2009) - Primeiros dados sobre a villa da Madanela (Coles de Samuel, Soure). Revista Portuguesa de Arqueologia. Lisboa. 12:1, pp. 201-210.

CORTEZ, Fernando Russel (1957) - Pesquizas arqueológicas submarinas no Atlântico. Viriatis - Arte, Arqueologia, Museologia: boletim do Museu de Grão Vasco. Viseu. 1:2, pp. 120-122.

CRUZ, Belchior da (1899-19oo) - Museu Municipal da Figueira da Foz - 1: Acquisições em 1898. O Archeologo Português. Lisboa. Vol. V, pp. 177-184.

DIAS, Alverinho (2004) - A história da evolução do litoral português nos últimos vinte milénios. In TAVARES, A.A.; TAVARES, M.J.F; CARDOSO, J.L. - Evolução geohistórica do litoral português e fenómenos correlativos: Geologia, História, Arqueologia e Climatologia. Lisboa: Universidade Aberta, pp. 157-170.

DIAS, J. Alves (1980) - Do "Pagus" ao Paio (Notas sobre a administração Romana em Portugal). Bracara Augusta. Braga. 34, pp. 659-672. Em colaboração com A. H. de Oliveira Marques.

FABIÃO, Carlos (1998) - O vinho na Lusitânia: reflexões em torno de um problema arqueológico. Revista Portuguesa de Arqueologia. Lisboa. 1:1, pp. 169-198.

FABIÃO, Carlos (2004) - Centros oleiros da Lusitania: balanço dos conhecimentos e perspectivas de investigação. In BERNAL, D.; LAGOSTENA, L., eds. - Figlinae Baeticae: talleres alfareros y producciones cerâmicas en la Bética romana. (ss. II a.C. - VII d.C.): actas del Congreso Internacional (Universidad de Cádiz, 12-14 de Noviembre de 2003). Oxford: Archaeopress, pp. 379-410. (BAR Internacional Series; 266)

FERNANDES, A. de Almeida (1999) - Toponímia portuguesa (exame a um dicionário). Arouca: Associação para a defesa da Cultura Arouquense.

FERREIRA, Ana; PINTO, Sónia (2017) - Análise e Diagnóstico Património Classificado e Referenciado - Documento final. Secção 2 Carta municipal de arqueologia. Divisão de Urbanismo - subunidade de planeamento; Divisão de Cultura. Câmara Municipal da Figueira da Foz. Acessível na Biblioteca do Museu Municipal Santos Rocha.

FRADE, Helena; MOREIRA, J. Beleza (1992) - A arquitectura das termas romanas de S. Pedro do Sul. Espacio, Tiempo y Forma, Serie II, Historia Antigua № 5 . UNED: Facultad de Geografia e Historia, pp. 515-544.

FUENTES SÁNCHEZ, J. Luis (2017) - Nuevo ejemplo de mortero Dramont Di, hallado en Laminium (Alhambra, Ciudad Real). Alebus. Elda. 10-12, pp. 155-192. N.- dedicado a: Investigaciones ibéricas, romanas y medievales 2000-2015.
HEVIA GONZÁlEZ, Susana; MONTES LÓPEZ, Ruben (2009) - Cerámica común del siglo I d.C. en el castro del Chao Samartín (Grandas de Salime, Asturias): notas sobre el repertorio en un ambiente militarizado. In: MORILLO, A.; HANEL, N.; MARTÍN, E., ed. - Limes XX: estudios sobre la frontera romana. Madrid: Consejo Superior de Investigaciones Cientificas. Vol. 2, pp. 639-654 (Anejos de Gladius; 13)

IMPERIAL, Flávio (2017) - O Sítio arqueológico de Maiorca no contexto da conquista romana do ocidente peninsular. Lisboa: Universidade de Lisboa, Faculdade de Letras.

JONCHERAY, J.P. (1972) - Contribution a l'étude de l'Epave Dramont D, dite "des pelvis». Cahiers d'Archeologie Subaquatique. Antibes. I, pp. 11-34.

LUEZAS PASCUAL, R. Aurora (2001) - Cerámicas comunes de importación de época romana en el Municipium Calagurris Ivlia (Calahorra, La Rioja). Kalakorikos. Calahorra. 6, pp. 71-10o.

MANTAS, Vasco (1999) - As villae marítimas e o problema do povoamento do litoral português na época romana. In GORGES, Jean-Gérard; RODRÍGUEZ MARTIN, F. Germán, ed. - Économie et Territoire en Lusitanie romaine: actes et travaux. Madrid: Casa de Velázquez, pp. 135-156 (Casa de Velázquez; 65).

MORAIS, Rui (2004) - Os almofarizes béticos em Bracara Augusta. In BERNAL, D.; LAGOSTENA, L., ed. - Figlinae Baeticae: talleres alfareros y producciones cerâmicas en la Bética romana. Oxford: Archaeopress. Vol. II, pp. 567-570 (BAR Internacional Series; 266)

MOSCARDÓ SABATER, Emili (2008) - El poblamiento rural romano en el território Norte de Dianium. La comarca de La Safor-Valldigna (Valencia). Saguntum, 4O, pp. 177-192.

MOTA, Nuno; GRILO, Carolina; ALMEIDA, Rui de; FILIPE, Victor (2016-2017) - Apontamento crono-estratigráfico para a topografia histórica de Olisipo. A intervenção arqueológica na rua de São Mamede (Via Pública - 19), Santa Maria Maior, Lisboa. CIRA Arqueologia 5, Câmara Municipal de Vila Franca de Xira, pp. 149-206.

PENAJOIA, Marco (no prelo) - Elementos para o Estudo da Ocupação Romana na Foz do Mondego. Colóquio Santos Rocha Arqueologia e Territórios da Figueira da Foz. Câmara Municipal da Figueira da Foz/Instituto de Arqueologia - FLUC.

PENAJOIA, Marco (2012) - A Questão portuária em torno de Montemor-o-Velho: Estudo de Arqueologia. Colecção Memória e Identidade, Câmara Municipal, Montemor-o-Velho.

PENAJOIA, Marco (2013) - Introdução ao estudo das planimetrias antigas: foto interpretação dos sítios arqueológicos de Sevelha e Vinha Velha. Monte Mayor - a terra e a gente. Montemor-o-Velho. 8:14, pp.149-151. 
PENAJOIA, Marco (2014-2015) - Território de Abrunheira, Verride e Vila Nova da Barca: bases para o seu estudo arqueológico e patrimonial: relatório técnico. Verride: União das Freguesias de Abrunheira, Verride e Vila Nova da Barca.

QUARESMA, J. Carlos (2006) - Almofarizes béticos e lusitanos: revisão crono- morfológica de alguns tipos. Revista Portuguesa de Arqueologia. Lisboa. 9:1, pp. 149-166.

RIBEIRO, Nuno; JOAQUINITO, Anabela.; PEREIRA, Sérgio (2010) - O Podomorfismo na Arte Rupestre da Fachada Atlântica, que significado?, Actas do VEncontro de Arqueologia do Sudoeste Peninsular, 18-20 Novembro de 2010, Almodôvar. Câmara Municipal de Almodôvar.

ROCHA, A. dos Santos (1897) - Fornos luso-romanos da freguesia de Brenha. In Memórias sobre a Antiguidade, Figueira da Foz: Imprensa Lusitana, pp. 259-264.

ROCHA, A. dos Santos (1905) - O Museu Municipal da Figueira da Foz: Catálogo Geral. Figueira da Foz: Imprensa Lusitana.

ROCHA, A. dos Santos (1909) - O castro do Bizorreiro de Castella. Boletim da Sociedade Arqueológica Santos Rocha.

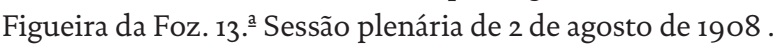
N.o 9 , pp. $245^{-246}$.

ROCHA, Artur (2016) - Peça do mês: almofariz. Museu do dinheiro, o1/24. Banco de Portugal. Lisboa.

RUIZ ZAPATERO, Gonzalo (1988) - La prospección arqueológica en España: passado, presente y futuro. Arqueologia Espacial. Lisboa, Tomar. 12, pp. 33-48.

SEPÚLDEVA, Eurico; SANTOS, Patrícia A.; FARIA, J. Carlos; FERREIRA, Marisol (2007) - Cerâmicas romanas do lado ocidental do castelo de Alcácer do Sal, 5: almofarizes de produção bética, pesos e cossoiros. Revista de Arqueologia. Lisboa. 10:2, pp. 255-284.

SILVA, R. Banha da (2015) - Um almofariz itálico com "marca de oleiro" de M. COMINIVS SATVRNINVS, de Lisboa. Lisboa: R.B. Silva (Estudos e relatórios de Arqueologia Tagana; 4).

TRELIS MARTÍ, Julio (2012) - La Canyada Joana (Crevillent-Alicante): una villa romana del ager ilicitanus. Anales de Prehistoria y Arqueología. Murcia. N. 27-28 (2011-2012). N.․e especial: NOGUERA CELDRÁN, J. M.; ANTOLINOS MARÍN, J. A., coord. - De vino et oleo Hispaniae. Áreas de producción y procesos tecnológicos del vino y el aceite en la Hispania romana. Coloquio Internacional, Universidad de Murcia, pp. 293-303

VILAÇA, Raquel (1988) - Subsídios para o estudo da Pré-História recente do Baixo Mondego. Trabalhos de Arqueologia 05. IPPC, Lisboa.

\section{CARTOGRAFIA}

PORTUGAL. Direção dos Trabalhos Geodésicos, Corográficos e Hidrográficos do Reino (1858) - [Planta Provisória dos Campos Inundados pelas Máximas Cheias do Mondego, seus afluentes e valas desde Coimbra à sua Foz na Vila da Figueira]. 1 planta para servir de base às disposições do $\$$ 2..$^{\circ}$ do artigo 3. . da Lei de 12 de agosto 1856 , levantada sob a direção do Conselheiro F. Folque, Brig. Grad. Dir. dos Trab. Geod. Corog. e Hidrog. do Reino, pelo Chefe da Secção Hidrogr. e Cap. Ten. da Armada F. M. P. da Silva e mais oficiais que o coadjuvaram.

PORTUGAL. Direção Geral dos Trabalhos Geológicos e Topográficos (1917) - [Carta de Portugal]. Escala 1:50.00o. 1 carta. Folha N.ำ 12-C. Ampliada e retificada na Direção Geral dos Trabalhos Geológicos e Topográficos no ano de 1901. Acessível no Arquivo Histórico do Museu Municipal Santos Rocha. Figueira da Foz

PORTUGAL. Instituto Geográfico (1866) - [Carta corográfica do reino de Portugal]. Escala 1:100.00o. 1 carta. Folha n. ${ }^{\circ}$ 13. Redigida e gravada no instituto Geográfico, sob a direção do Conselheiro F. Folque. Acessível no Arquivo Histórico do Museu Municipal Santos Rocha. Figueira da Foz. 


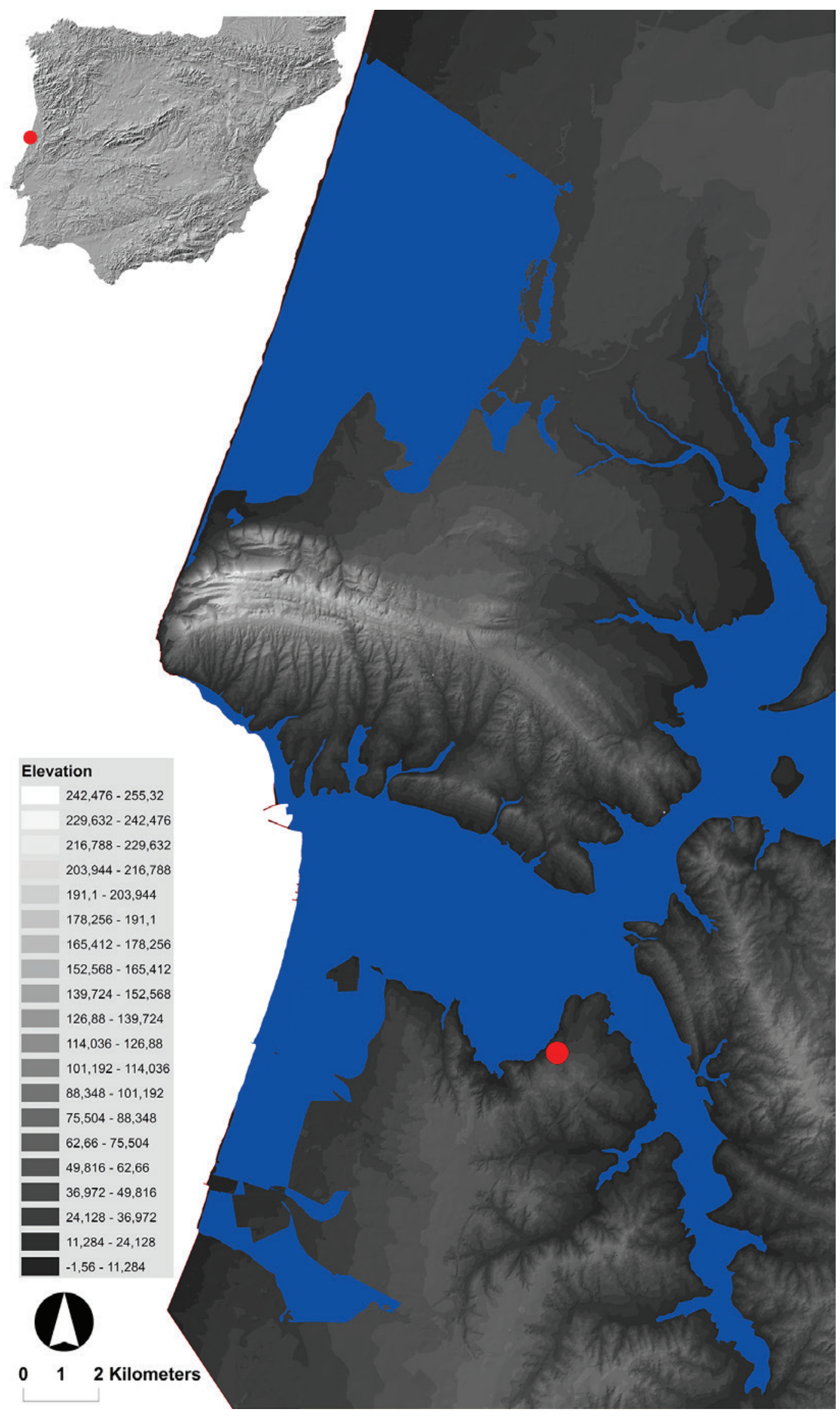

Figura 1 - Localização da Igreja Velha do Negrote. 


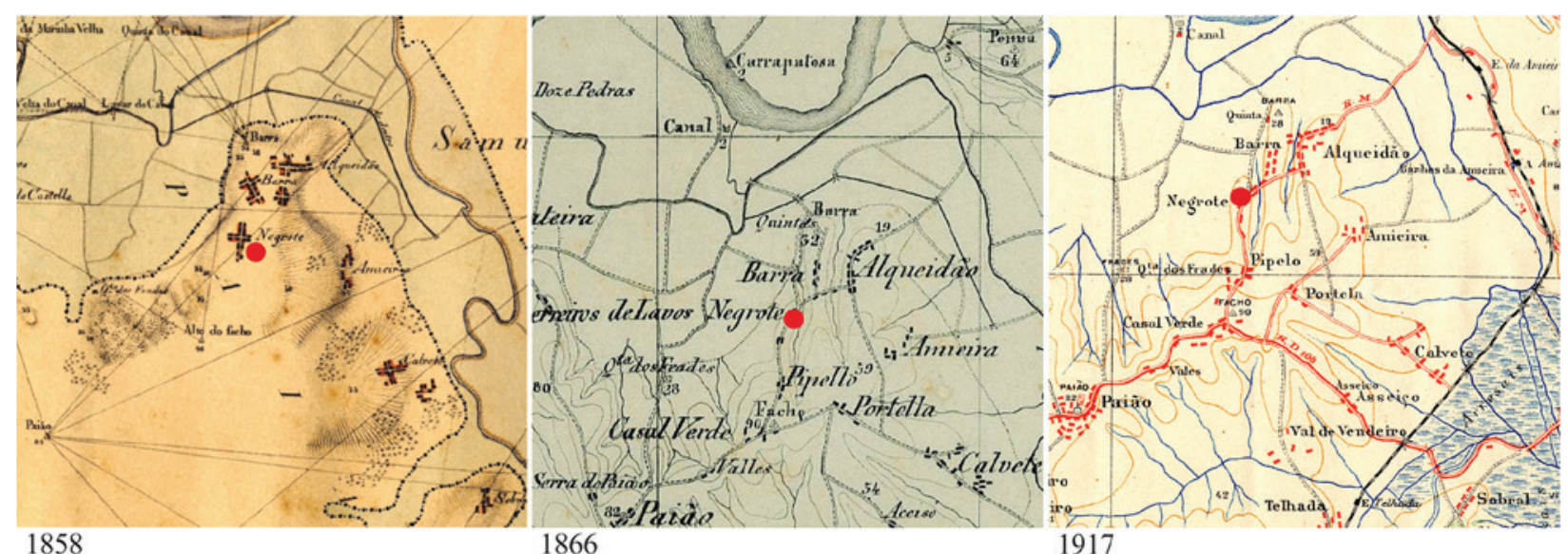

Figura 2 - Localização da Igreja Velha do Negrote a partir de cartografia histórica. Excertos adaptados de: Direção dos trabalhos geodésicos, corográficos e hidrográficos do Reino (1858); Instituto Geográfico (1866); Direção Geral dos Trabalhos Geológicos e Topográficos (1917).

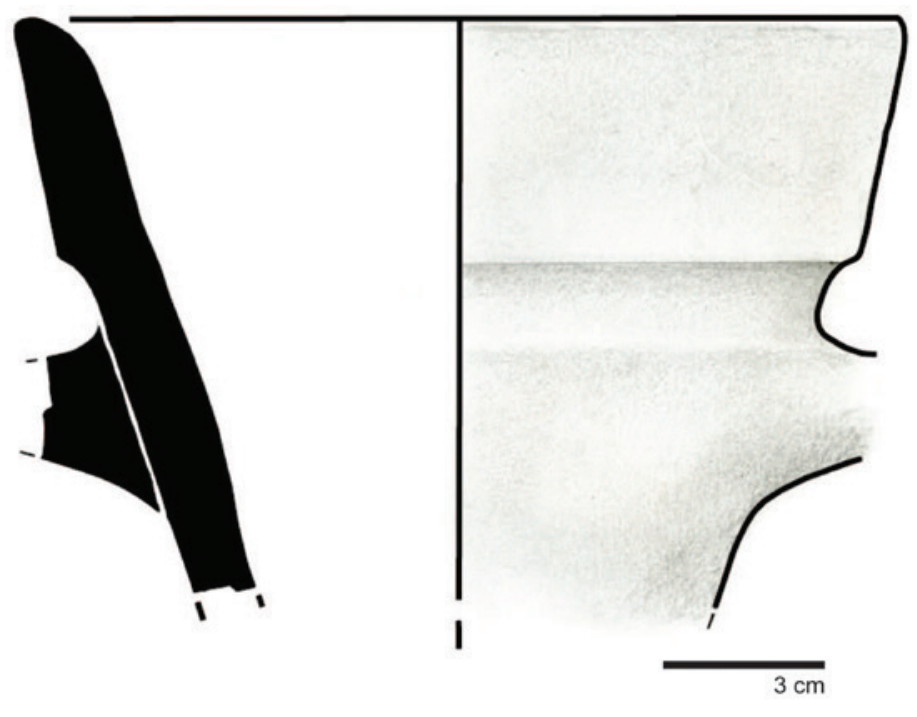

Figura 3 - Ânfora Haltern 7o. Escala $3 \mathrm{~cm}$. 

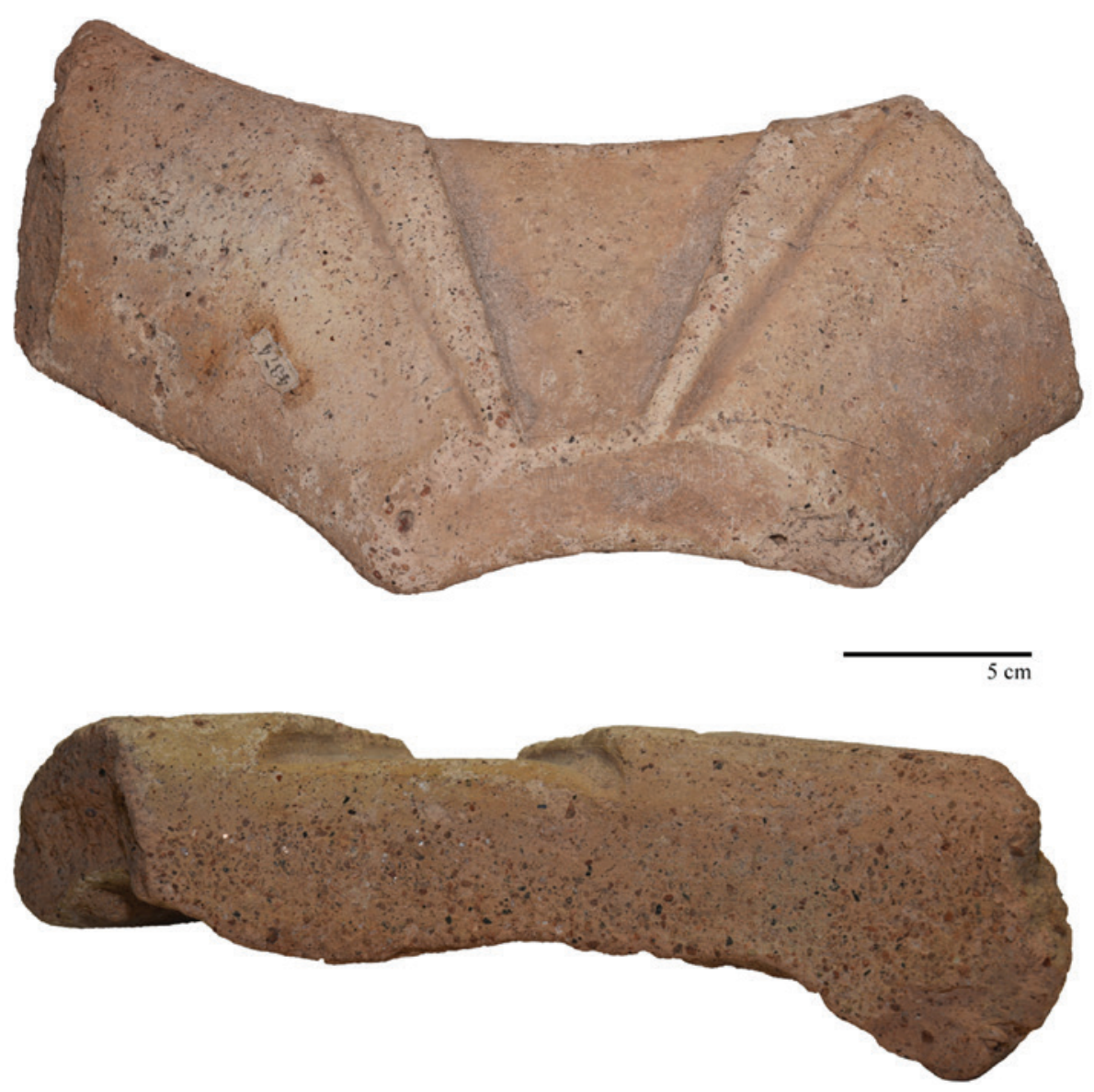

Figura 4 - Registo fotográfico do fragmento de almofariz. Escala $5 \mathrm{~cm}$.

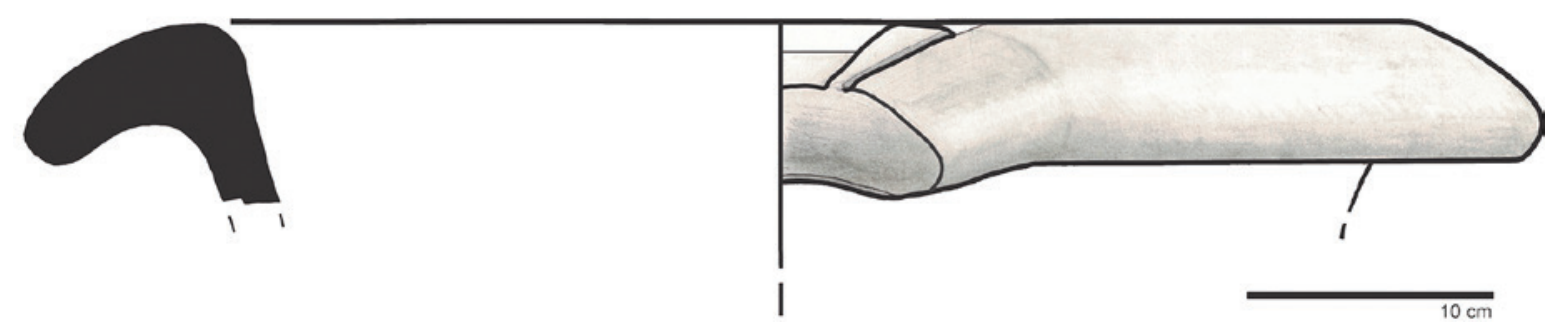

Figura 5-Almofariz Dramont D2. Escala $10 \mathrm{~cm}$. 


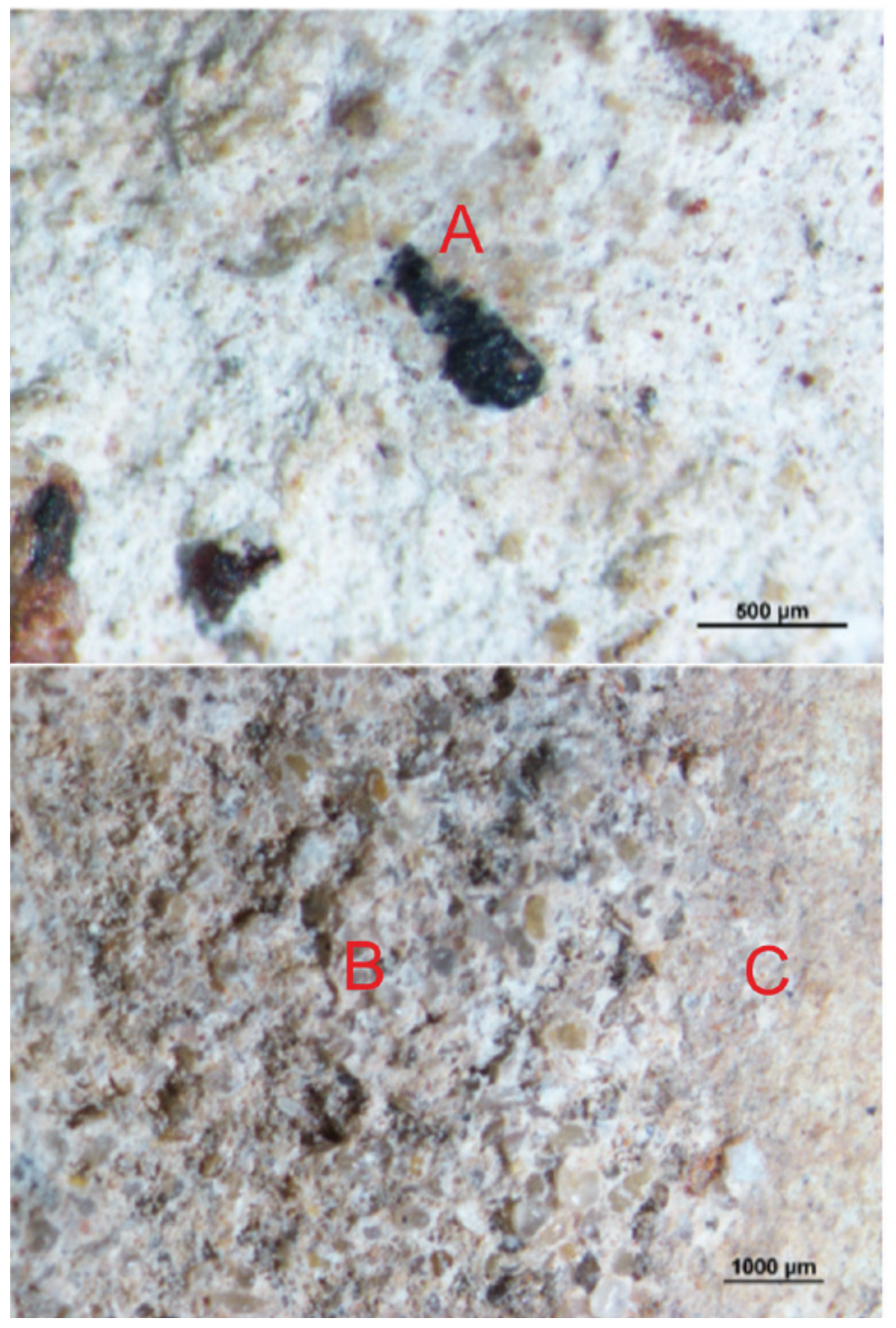

Figura 6 - Fotomicrografia executada à pasta do almofariz. A - presença de piroxenas; $\mathrm{B}$ - argamassa incrustada junto ao sulco do vertedor; $\mathrm{C}$ - pasta original. Laboratório de petrologia (DCT-UC). 


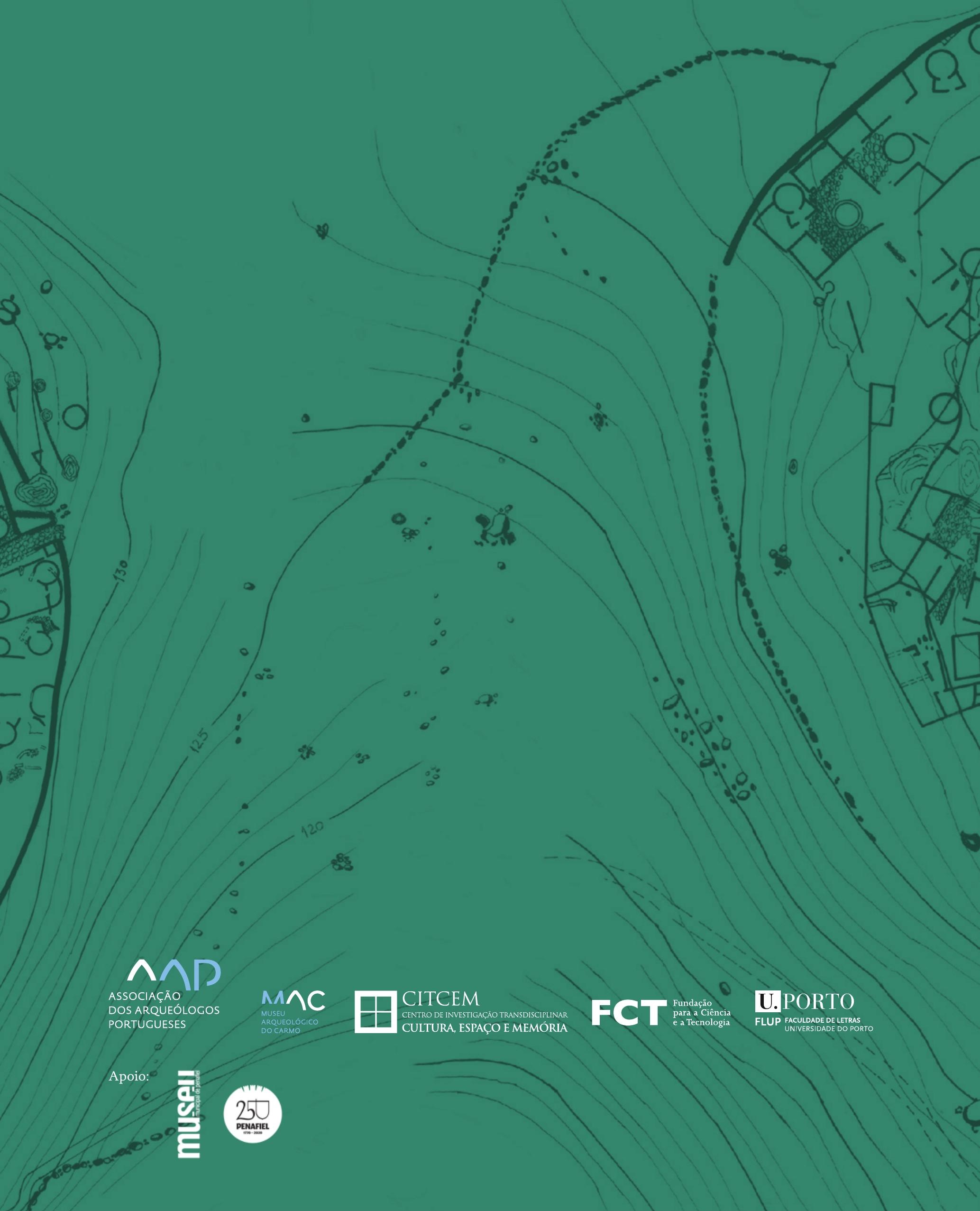

